\title{
Population status and feeding ecology of common bushbuck (Tragelaphus scriptus) in Moledo Forest, west Gojjam, Ethiopia
}

\section{Aynalem Sinshaw}

Debre Markos University

Mesele Tamene ( $\square$ mesyih@gmail.com )

Addis Ababa University College of Natural Sciences https://orcid.org/0000-0001-7245-9177

\section{Research article}

Keywords: Common bushbuck, Diet, Moledo Forest, Population estimate, Sex ratio

Posted Date: May 23rd, 2020

DOI: https://doi.org/10.21203/rs.3.rs-27459/v1

License: (c) (i) This work is licensed under a Creative Commons Attribution 4.0 International License.

Read Full License 


\section{Abstract}

Background Common Bushbuck (Tragelaphus scriptus) is one of the most widely distributed antelope species in African continent and use a wide variety of habitat types. A study on population status and feeding ecology of common bushbuck in Moledo Forest, West Gojjam, Ethiopia was carried out from September 2017 to August 2018 during wet and dry seasons. Data were collected using total count method and focal sampling technique. Then, the collected data were analyzed using descriptive statistics and compared with t-test for population status and percentage contribution of food items. Plant species consumed were compared with Chi-square test between seasons.

Results The result indicated that the total numbers of bushbuck population were 18 and 28 during dry and wet seasons, respectively. There was a significant difference $(t=0.61, d f=4, p<0.05)$ in bushbuck population during both seasons. Sex ratio of adult male to adult female was1.4:1. On the other hand, 20 plant species belonging to 11 families were recorded as food for study animal. Food items were significantly differed between seasons $\left(\{\{\backslash \mathrm{chi}\}\}^{\wedge}\{2\}=930.88, \mathrm{df}=1, \mathrm{p}<0.05\right)$. Their food items mainly constituted $50 \%$ shrub, $30 \%$ herb and $20 \%$ tree. Young leaves contributed to $40 \%$ of their diet followed by mature leaves $26 \%$. On the other hand, flowers contributed the least (6\%) for their diet. There was a significant variation $\left(\{\{\backslash \mathrm{chi}\}\}^{\wedge}\{2\}=98, \mathrm{df}=10, \mathrm{p}<0.05\right.$ ) in parts of plant consumed by common bushbuck in the study area.

Conclusion There are some threats associated with common bushbuck in the study area such as livestock grazing, habitat encroachment, fire wood collection, predation and hunting. Therefore, immediate attention needs to be paid to conserve the study animal in particular and other wildlife in general.

\section{Background}

Common bushbuck (Tragelaphus scriptus) is a medium-sized antelope vary considerably in color ranging from bright chestnut to dark-brown. The ram is usually a darkish brown and the ewe a lighter reddish brown [1]. It has thick tail. Adult males stand $0.8 \mathrm{~m}$ at the shoulder with an average weight of $40 \mathrm{~kg}$ while adult females stand $0.7 \mathrm{~m}$ at the shoulder with an average weight of $30 \mathrm{~kg}$ [2]. Only males have horns. An average horn length is $26 \mathrm{~cm}$ [3]. It is widely distributed in Africa and it may be expected to use a wide variety of habitat types [4]. Bushbucks are always found near a permanent water source and prefer dense bush and forest margins. Bushbucks are found in suitable habitat comprising densely structured vegetation south of the Sahara through west, central, east and south-east Africa [3]. Common bushbucks are mixed feeders. They are both grazers and browsers [5]. Bushbuck is polyganandrous meaning multiple males and females share one another. The gestation period is 200 days [1]. They usually live alone, but occasionally spend their time in pairs or even in small groups of adult females, adult females with young or adult males [6]. 
Less attention is given to study common bushbuck in most its range. In addition, unprotected areas are not the focus of many researchers even if they harbor variety of floral and faunal species. There was no any recorded information about the ecology of bushbuck in Moledo Forest which is found in west Gojjam. Hence, for applying effective conservation, there is a need to collect enough information about the species found in the area. Therefore, the present study aimed to reveal information about population status and feeding ecology of common bushbuck in the study area.

\section{Materials And Methods}

\section{Description of the Study Areas}

The study was conducted in Moledo Forest which is found in Dega Damot Woreda, West Gojjam Zone, Amhara Regional State. It is located $415 \mathrm{~km}$ Northwest of Addis Ababa between $11^{0} 28^{\prime} 22^{\prime \prime} 10^{\circ} 58^{\prime} \mathrm{N}$ latitude and $11^{\circ} 51^{\prime} 32^{\prime \prime} 38^{\circ} 22^{\prime} \mathrm{N}$ and $36^{0} 2^{\prime} 31^{\prime \prime}$ and $37^{0} 11^{\prime} 54^{\prime \prime} \mathrm{E}$ longitudes (Fig. 1). The total area of the forest is 180 ha. Its average altitude is $2961 \mathrm{~m}$ a. s. I. with maximum $3445 \mathrm{~m}$ and minimum $2477 \mathrm{~m}$ altitude a. s. I.

Figure 1

The annual temperature varies between $9.3^{\circ} \mathrm{C}$ to $18.3^{\circ} \mathrm{C}$ [7]. It has an average annual rainfall of $1653 \mathrm{ml}$. The area has a unimodal rainfall pattern which usually starts in May and stops in October.

The area consists of natural forest and dominated by plant species such as Acacia abyssinica, Carissa edulis, Albizia shimperiana, Rosa abyssinica, Croton macrostachyus and Allophyllus abyssinicus [8]. The area also home to different animal species including common bushbuck (Tragelaphus scriptus), klipspringer (Oreotragus oreotragus), Bahor reedbuck (Redunca redunca), leopard (Panthera pardus), spotted hyenas (Crocuta crocuta), golden jackal (Canis aureus), reptiles, birds and amphibians [8].

\section{Methods}

\section{Population Estimation}

The quantitative data was collected from September 2017 to August 2018. To assess the population status of bushbuck, total count method was employed in blocks designed for this purpose. The counting blocks were separated through habitat based on natural boundaries such as streams, rivers, big trees and rocks. Counting was done at the same time through all habitats on foot with the help of other 10 trained people to avoid double counting [9]. Counting was made with naked eye and binoculars. Counting information such as number, sex, age, body size, coat color, structure of genital organs and the presence or absence of horns were used to determine sex of individuals. Body size, horn size and shape were used to determine age. Males are horned and dark-brown while females are hornless and light brown in color [11. Individuals which are small in size were recorded as young and large ones are adult. 


\section{Feeding Ecology}

To understand the feeding behavior of common bushbuck, focal sampling technique and direct observations were carried out to collect information such as type of food items consumed, parts of plant consumed and the time spent for foraging were recorded both during the wet and dry seasons. Foraging types including browsing and grazing were also recorded during both wet and dry seasons [10]. The location of each herd and the vegetation type at each location were recorded. An animal was followed during active feeding time to observe the plant species that were consumed [11]. The animal was observed from vantage point while consuming a particular plant species [12]. Plant species collected during field observation were taken to Bihar Dar University herbarium for identification purpose.

\section{Data Analyses}

Data were analyzed using SPSS software for windows version 20. Descriptive statistics for analysis of data and to show the result and t test for independent samples of population status and structure in different season, the percentage contribution of food items and the species of plants were consumed by the bushbuck were compared using Chi-square test between seasons.

\section{Results}

\section{Population Estimate}

A total of 18 individuals were counted during dry season with mean value $3.5 \pm 0.93$ and 28 individuals during the wet season with mean value $5 \pm 1.58$. There was a significant difference in the number of bushbuck individuals during the wet season and the dry season $(t=0.61, d f=4, p<0.05)($ Table1).

Table 1

Of the population recorded during the wet season, $25 \%$ adult males, $17.9 \%$ adult females, $28.6 \%$ subadult males, $14.3 \%$ sub adult females and $14.3 \%$ young. On the other hand, during the dry season, $22.22 \%$ were adult - males, $11.11 \%$ adult females, $27.77 \%$ sub-adult males, $11.11 \%$ sub-adult females and $16.662 \%$ young. There was no significant difference between sub-adult males and adult female $(t=1.5, d f=4, p>0.05)$, and also there was no significant difference among adult male and subadult female, young and adult male $(t=0.54, d f=4, p>0.05)$ and young and sub adult female $(t=0.54, d f=4, p>0.05)$. 
Out of the average of 23 individuals of common bushbucks observed $45.6 \%$ of individuals were subadults, $39.1 \%$ adults and $15.2 \%$ young. During study more sub-adult individuals were counted than adults and young once. Among the total population of common bushbucks sighted in Moledo Forest, males constituted $52.2 \%$ and females $32.6 \%$. However, the chi-square test analysis of sex structure showed that which is not statistically significant $=0.24, \mathrm{df}=1, \mathrm{p}>0.05$ ). And also age distribution was not significant statistically during wet and dry seasons ( $=1.62, \mathrm{df}=4, \mathrm{p}>0.05)$ (Fig. 2).

Figure 2

The population structure and proportion of various age-sex categories of the observed common bushbuck in Moledo forest are given in Table 2. The age sex ratio of subadult male to subadult female was 2:1 during the wet season whereas adult male to adult female was 2:1 during the dry season.

Table 2

\section{Feeding Ecology}

A total of 985 feeding activities were recorded. From these total observations 564 were observed during wet season and 421 were observed during dry season. According to the result, 20 plant species belonging to 11 families were recorded serving as food for common bushbuck in Moledo Forest. Half $(50 \%)$ of the diet were shrub, $30 \%$ were herb and $20 \%$ were tree species. Food items were significantly differed between seasons $(=930.88, \mathrm{df}=1, \mathrm{p}<0.05)($ Table 3$)$.

Table 3

Of the identified list of plant species, $25 \%$ were Poaceae, $10 \%$ were Polygonaceae, $15 \%$ were Rosaceae , $10 \%$ were Acanthaceae, $10 \%$ were Myrsinaceae and the other families shared $5 \%$ (Fig. 3). The most commonly used plant species was Cynodon dyctylon (10.5\%), followed by Oplismenus composites $(9.8 \%)$ while Rumex nervosus vah/ was least used (0.5\%).

Figure 3

About $40 \%$ of the diet constituted young leaves followed by mature leaves (26\%). There was significant variation ( $=98, \mathrm{df}=10, \mathrm{P}<0.05$ ) in parts of plant consumed by common bushbuck (Fig .4). 
Figure 4

\section{Discussion}

In order to manage the population of common bushbuck properly and to take conservation measures accordingly, estimating their status, feeding ecology and identifying potential threats in the study area is important. And also separation of the study period into wet and dry seasons was important in order to observe the influence of the different seasons in the vegetation component and the distribution of animals of common bushbuck. In this study, more common bushbucks were counted during the wet season and also significantly differed from dry season because the wet season are more comfortable for shelter, food availability and development of different life forms such as tree, shrub and herbs. Similarly, [13] finding revealed that larger number of Minilik's bushbuck counted during wet season than dry season in Denkoro Forest. However, the present finding is contrasted with the finding of [14] where higher number of Minilik's bushbuck counted in dry season than wet season. This might be due to bushbuck migration to neighboring forest from study area. But, the breeding system is not affected by seasonal variation because the breeding of common bushbuck is not seasonal and young may be born at any time of the year [15].

The number of common bushbuck was very low in the study area when compared with number of Minilik's bushbuck counted by [13] in Denkoro Forest and [16] in Wof-washa forest. The low sighting of the animal in the study area probably due to its shy behavior and impact of hunting as the study area is unprotected.

Knowledge of sex ratio and age distribution among the mammalian populations is vital for evaluating the viability of the species as these variables reflect the structure and the dynamics of population [17]. Sex and age structure of a population at any given point of time are also indicators of the status of the population [18]. The result of the present study showed $52 \%$ of the population is composed of males. This might be because; males have larger home range than females so that they had higher possibility to be observed. In contrast, studies conducted in Denkoro Forest [13] and Wof-Washa Forest [16] indicated that the sex ratio were female biased toward. The record for young individuals was relatively small only $15.2 \%$ of population is composed of young during this study; this might be as a result of the highly cryptic adaptive behavior of young individuals common in such antelopes [19,20]. Moreover, they may be susceptible to predators at this stage as they are unable to escape

Utilization of habitat is often determined by the availability of cover and food and the rich plant growth [21]. So, the variation in the average number of individuals recorded in different habitat during the wet and dry seasons could be a result of changes in the abundance of resources required in different habitat types and the daily weather conditions. During the wet season, the solar radiation is shielded by the cloud cover, hence animals leave dense forests such as Riverine and Wood lands and move in to the open grass land for foraging, but during the dry season, they prefer dense forests such as Riverine and Wood lands dumne tn ho nrotontod from tho intoncivo colar radiation. And also these areas have water availability Loading [MathJax]/jax/output/CommonHTML/jax.js 
and green grasses. The other possible reason may also be their tendency to avoid predation in small population size as there is no more cover during the dry season due to defoliation. This is because bushbucks mostly defend themselves by hiding in dense area rather than combating, although males defend themselves when they are exposed. And also, during the dry season the frequency of hunting activity of local people greater than the wet season. Generally total individuals recorded in grass land significantly higher than the other habitat. This supports the findings of [13]. But in dry season $38.09 \%$ individual of common bushbuck were observed in Riverine forest because Riverine has all types of life forms, more water access and green grasses in dry season and $22.2 \%$ individual of common bushbuck were observed in wood land which has more food supply and it has canopy condition in dry season. However, the smallest number of common bushbuck recorded in grass land in dry season. During wet season the largest number of common bushbuck were recorded in grass land than other habitat because this habitat became green and owning to its openness which helps for bushbuck to control their enemies.

Knowledge of a species' diet is essential to understand its position in an ecosystem and to organize effective management plans for its conservation. During the present study, 20 plant species were observed as a food source of common bushbuck it includes in 11 families from which poaceae family the major food item which was significantly higher than roaceae family during wet season $\left(\chi^{2}=5.85, \mathrm{df}\right.$ $=1, P<0.05)$. The present study indicated that common bushbucks are mixed feeders, which rely on browsing shrubs, herbs and trees and grazing on a variety of grass species. This is similar to the findings of [18] for bushbuck and [22] and [10] for other ungulate species. Bushbucks spent more time feeding on herbaceous species and grasses during the wet season. However, during the dry season, more time spent feeding on shrubs and trees as the availability of grasses and annual herbs decreased. They consumed all plant parts; however, young leaves constituted the largest proportion (40\%) of their diet while shoots and stems were used least. [13] also reported similar observations, although [23] reported common bushbucks did not consume grass at all, grass species like Cynodon dyctylon, Plismenus composites, Oplismenus composites and Hemeda trianda were contributed a considerable percentage of the bushbuck diet, particularly during the wet season as observed in current study.

There are many conservation problems that could affect bushbuck population in the study area in the future. These threats are the results of increased human population in the adjacent areas of Moledo Forest. The threats in the study area include human-induced habitat loss and degradation through, livestock grazing, encroachment and hunting. As a result, the quality of the bushbuck habitat is deteriorating. Therefore, the area needs strong attention and immediate action under take proper conservation the study animal in particular and other wildlife of the area at large.

\section{Declarations}

\section{Acknowledgement}

We would like to thank Debre Markos University for providing fund to conduct the present study. 


\section{Authors' contributions}

AS contributed in data collection and analysis. MY wrote the manuscript. Both authors read and approved the final manuscript.

\section{Funding}

The work was supported by Debre Markos University

\section{Availability of data and materials}

The datasets of this study will be available from corresponding authors on genuine request.

\section{Ethics approval and consent to participate}

Not applicable. We did research on animals and did not handle them along protected areas. Therefore, ethics approval/permission was not required. The national guideline exempt requiring formal ethical approval or permission if there is no contact between the researcher(s) and the study animal.

\section{Consent for publication}

Not applicable.

\section{Competing interests}

The authors declare that they have no competing interests.

\section{References}

1. Kingdon J. Field Guide to African Mammals London. Academic Press. solutions: Biol Conserv. 1997; 160:80-96.

2. Walker $\mathrm{CH}$. Signs of the wild: a field guide to the spoor and signs of the mammals of Southern Africa 5th edn.Cape Town, Struik; 1996.

3. Skinner J, Smithers RHN. The Mammals of the South Africa Sub region. 2nd edn. University of Pretoria; 1990.

4. East R. African antelope database1998 Gland, Switzeland:Cambridge, UK:IUCN. Conserv Bongo of Antel. 1999;25:13-21.

5. Bender DJ, Contreras TA, Fahring L. Habitat loss and population decline:a meta- analysis of the patch size effect. Ecology. 1998;79:517-33.

6. Seymour R. Ecological separation of greater kudu nyala and bushbuck at Londozi C. C. Afr Ecol J. 2002;4:137-46.

7. Agriservice Ethiopia...Baseline Survey Analysis Report, Unpublished Dega Damot Woreda Integrated 
8. DDWFEO. Dega Damote Woreda Finance and Economic Organization submitted information from land and topography of Woreda Keble; 2014.

9. Anderson DR, Bunahamand KP, Crain BR. A long Linear Model Approach to Estimate Population size. Using the Line Transect Sampling Method of Ecology; 1978.

10. Owen-Smith N. Tragelaphus strepsiceros Greater Kudu In: Parambikulam Wildlife Sanctuary Karalla, India Biological Conservation, Baltimore, Pelea. 2013. p. 134-141.

11. Milton K. Nutritional characteristics of wild primate foods: Do the diets of our closest living relatives have lessons for us? Nutrition. 1999;15:488-98.

12. Wemmer C, Kunz T, Lundie-Jekins G, Shea W. Mammalian Sign, In: Wilson DE, Cole FR, Nichols JD, Rudran R, Foster MS, editors. Measuring and Monitoring Biological Diversity, Standard methods for mammals, Smithsonian Institution, USA. 1996; p. 176-198.

13. Dereje Y, Yosef M, Nekele A. Population ecology of Menelik's Bushbuck (Tragelaphus scriptus menliki, Neumann1902) From Denkoro Forest National park: Northern Ethiopia. Inter J Ecol Environ Sci. 2011;37:1-13.

14. Abebayehu D, Tilaye W. Population density, structure and grouping pattern of Menelik's bushbuck in the Menagesha Suba state Forest:Ethiopia. Eth J Sci. 2012;35(2):129-34.

15. Coates GD, Downs CT. Survey of the status and management of sympatric bushbuck and nyala in KwaZulu-Natal:South Africa. S Afr J Wildl Res. 2005;8:35-179.

16. Brnesh H, Tsegaye G, Tadese H, Gelaye G. The status and feeding ecology of Menelik's Bushbuck (Neumann, 1902) in Wof Washa Forest, North Shoa: Ethiopia. Inter J Cur Res. 2015;7(5):16366-70.

17. Wilson DE, Cole FR, Nichols JD, Rudran R, Foster MS. Measuring and Monitoring Biological Diversity: Standard Methods for Mammals. Washington DC: Smithsonian Institution Press; 1996.

18. Wronski T, Apio A, Plath M Activity patterns of bushbuck (Tragelaphus scriptus) in Queen Elizabeth National Park. Behav Proc. 2006; 73: 333-341.

19. Irby LR. Mountain reedbuck activity patterns in the Loskop Dam Nature Reserve. S Afr J Wildl Res. 1981;11:115-20.

20. Taylor WA. Factors influencing productivity in sympatric populations of mountain Reedbuck and grey rhebok in the Sterkfonte in Dam Natural PhD. Thesis, University of Pretoria, Pretoria; 2004.

21. Dankwa D, Wiredu B, Euler DL. Bushbuck (Tragelaphus scriptus) habitat in Mole National Park. Ghana Afri J Ecol. 2002;40:35-41.

22. Hofmann R. Evolutionary steps of eco-physiological adaptation and diversification of ruminants a comparative view of their digestive system. Otheocologia. 1989;78:443-57.

23. Apio A, Wronski T. Foraging behaviour and diet composition of bushbucks (Tragelaphus scriptus Pallas 1776) in Queen Elizabeth National Park; Western Uganda. Afr J Ecol. 2005;43:225-32.

\section{Tables}




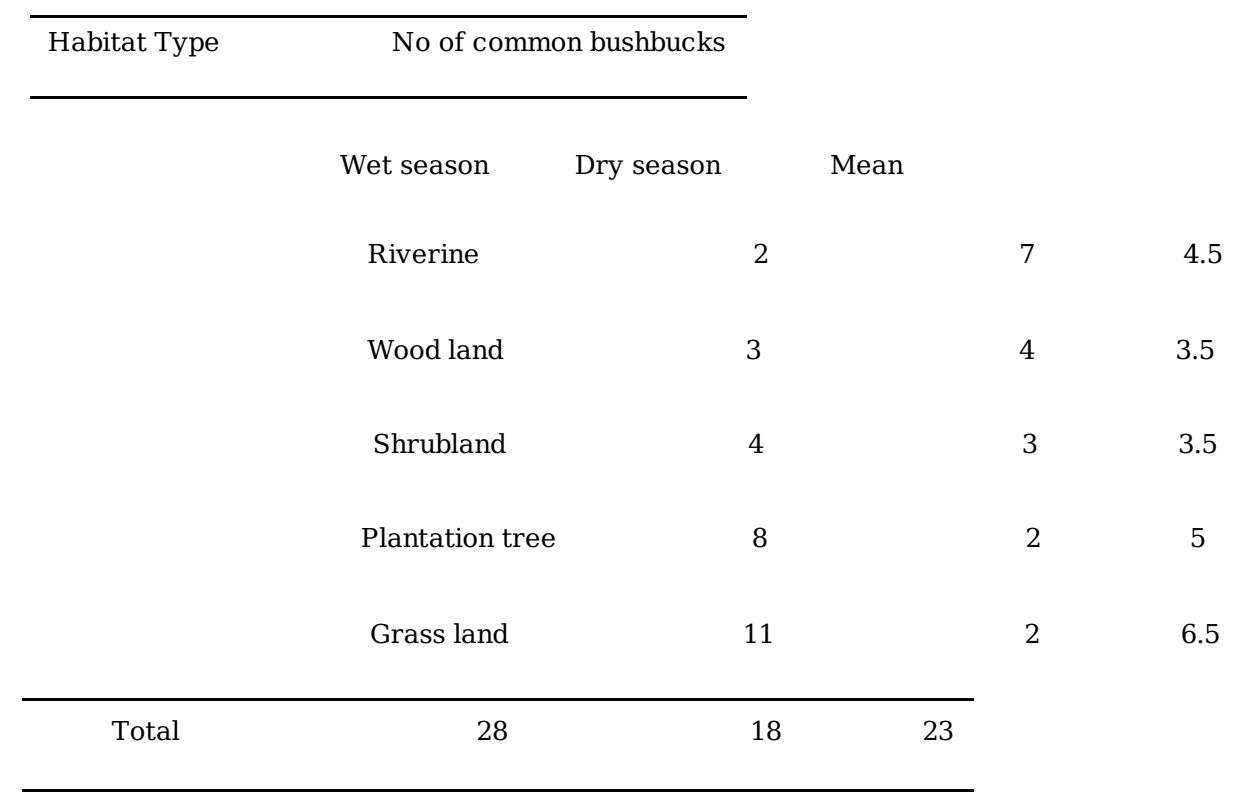

Table 2. Proportions of different age and sex categories of the common bushbuck recorded during the dry and wet seasons.

\begin{tabular}{cccc}
\cline { 2 - 3 } & \multicolumn{2}{c}{ Season } & \\
\cline { 2 - 3 } & AM: AF & SAM: SAF & Y: ADF \\
\hline Wet & $1.4: 1$ & $2: 1$ & $1: 1.75$ \\
Dry & $2: 1$ & $1.3: 1$ & $1: 1$ \\
\hline
\end{tabular}

Table 3. List of plant species, frequency and percentage contribution in the diet of common bushbuck in Moledo Forest.

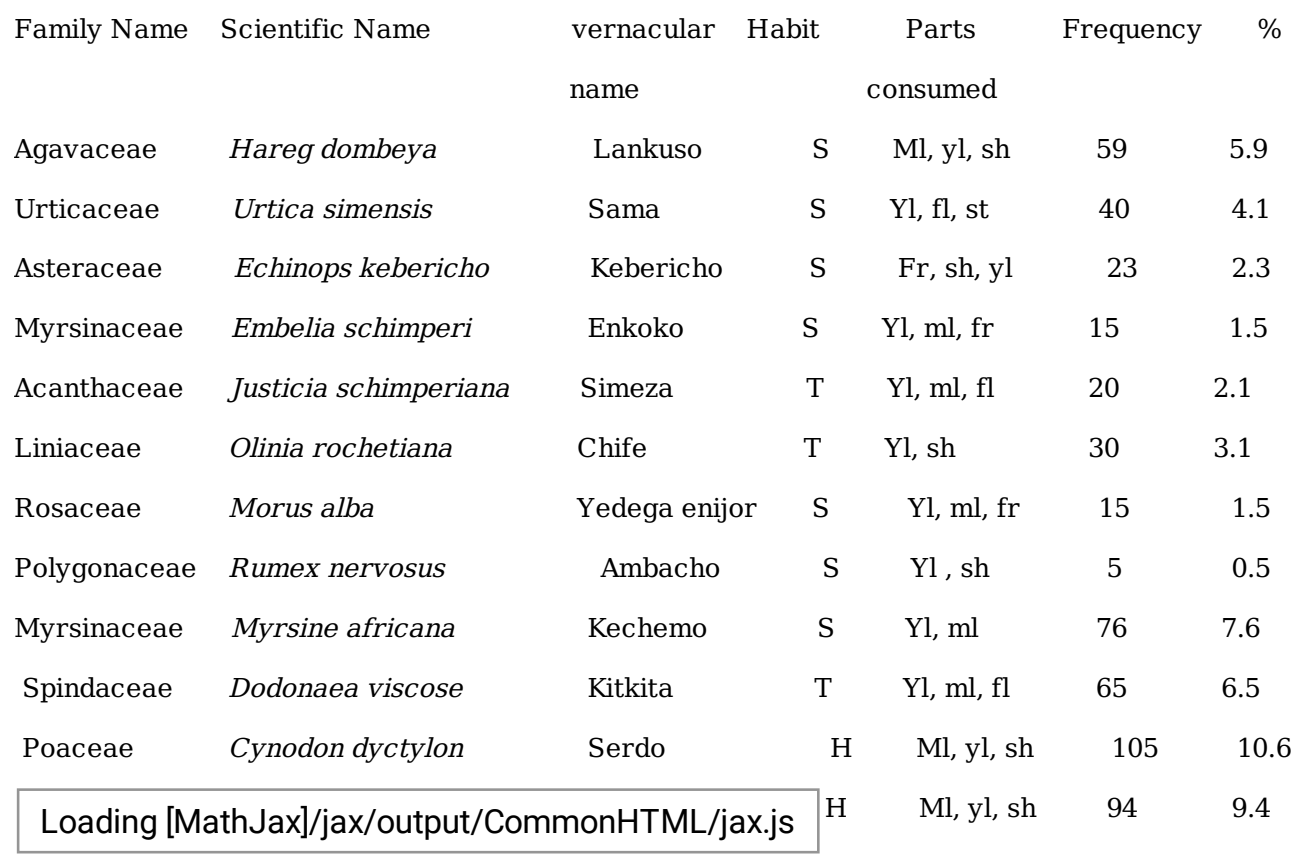




$\begin{array}{llllllc}\text { Poaceae } & \text { Festuca abyssinica } & \text { Yedaget sar } & \text { H } & \text { Ml, yl, } & 95 & 9.5 \\ \text { Poaceae } & \text { Andropogon gayanus } & \text { Gaja } & \text { H } & \text { Ml, yl, sh } & 98 & 9.8 \\ \text { Rosaceae } & \text { Rossa abyssinica } & \text { Kega } & \text { S } & \text { M l, yl, sh } & 78 & 7.8 \\ \text { Cynaceae } & \text { Carissa spinarum } & \text { Agam } & \text { S } & \text { Yl } & 52 & 5.2 \\ \text { Rosaceae } & \text { Hagenia abyssinica } & \text { Kosso } & \text { T } & \text { Yl } & 35 & 3.5 \\ \text { Poaceae } & \text { Hemeda trianda } & \text { Dega Senbelet } & \text { H } & \text { Ml, yl,sh } & 65 & 6.5 \\ \text { Polygonaceae } & \text { Wmex nepalensis } & \text { Yewusha Milas } & \text { H } & \text { Ml, yl,st } & 10 & 0.1 \\ \text { Acanthaceae } & \text { Acanthus sennii } & \text { Kosheshila } & \text { S } & \text { Yl } & 5 & 0.5 \\ \text { Total } & & & & & 985 & 100\end{array}$

- Key (T=Tree, H=Herb, S=Shrub, Yl=Young leaves, Ml=Mature leaves, St=Stem, Sh=Shoot, Fl=Flower, Fr=Fruit)

\section{Figures}




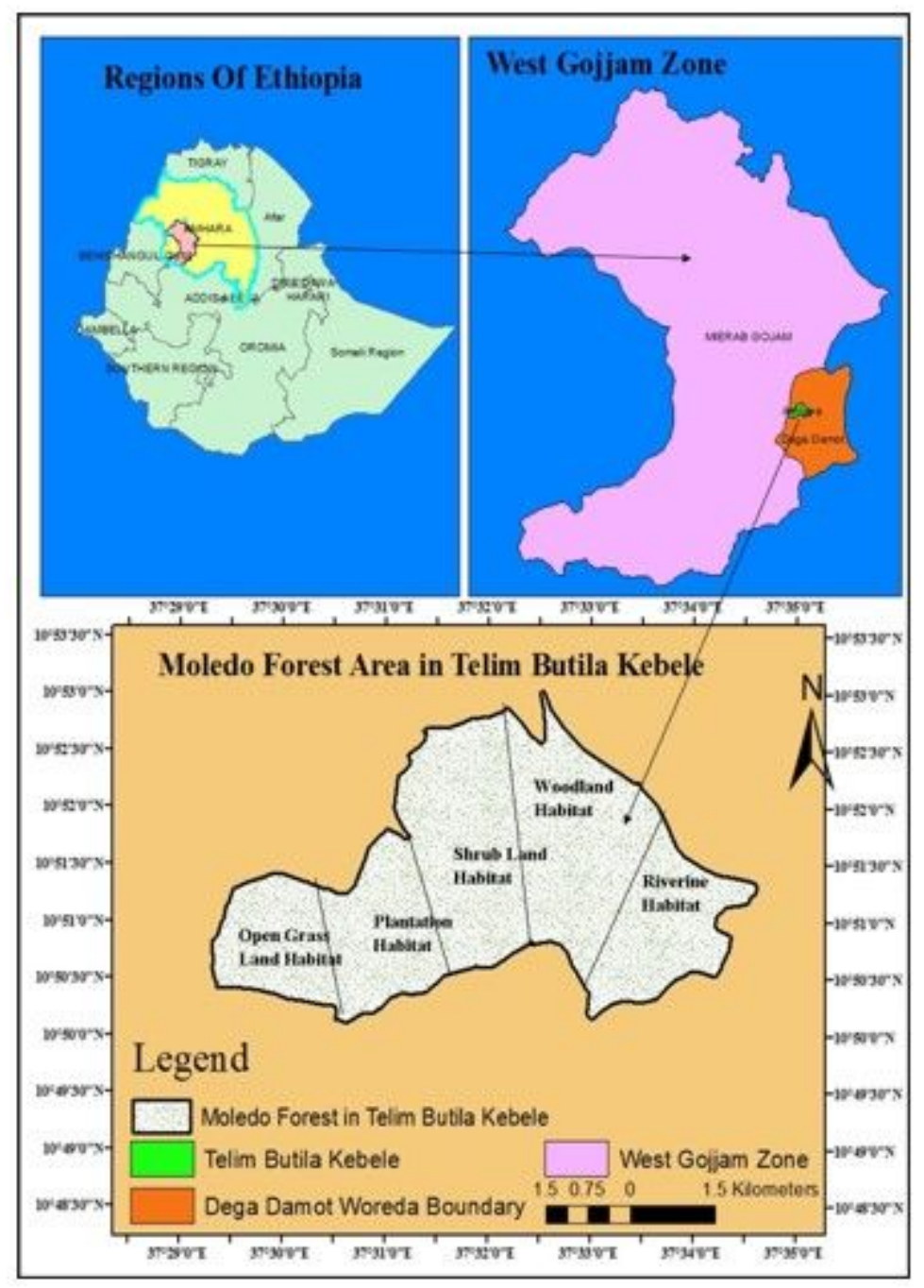

\section{Figure 1}

The study was conducted in Moledo Forest which is found in Dega Damot Woreda, West Gojjam Zone, Amhara Regional State. It is located 415km Northwest of Addis Ababa between 110 28' 22" 100 58' N latitude and $11051^{\prime} 32^{\prime \prime} 38022^{\prime} \mathrm{N}$ and $36^{\wedge} 02^{\prime} 31^{\prime \prime}$ and $37^{\wedge} 011^{\prime} 54^{\prime \prime} \mathrm{E}$ longitudes (Fig. 1). The total area of the forest is 180 ha. Its average altitude is $2961 \mathrm{~m}$ a. s. I. with maximum $3445 \mathrm{~m}$ and minimum $2477 \mathrm{~m}$ altitude a. s. I. 


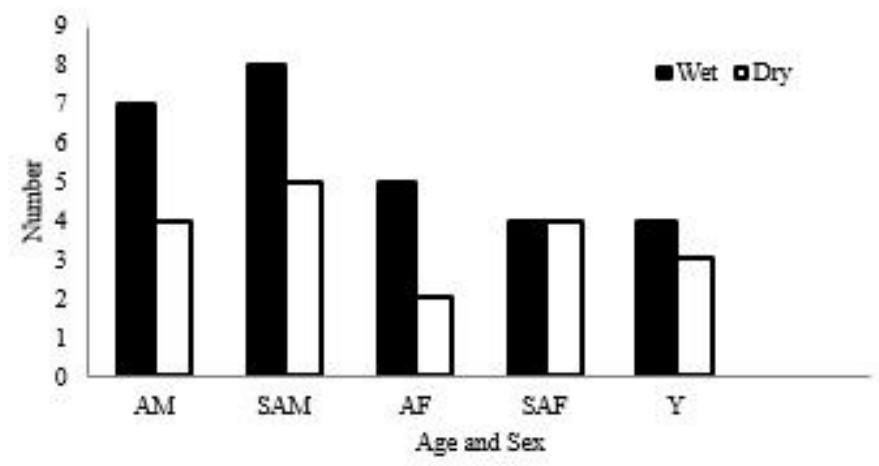

Figure 2

Out of the average of 23 individuals of common bushbucks observed $45.6 \%$ of individuals were subadults, $39.1 \%$ adults and $15.2 \%$ young. During study more sub-adult individuals were counted than adults and young once. Among the total population of common bushbucks sighted in Moledo Forest, males constituted $52.2 \%$ and females $32.6 \%$. However, the chi-square test analysis of sex structure showed that which is not statistically significant $\left(\chi^{\wedge} 2=0.24, d f=1, p>0.05\right)$. And also age distribution was not significant statistically during wet and dry seasons $\left(\chi^{\wedge} 2=1.62, \mathrm{df}=4, \mathrm{p}>0.05\right)$ (Fig. 2 ).

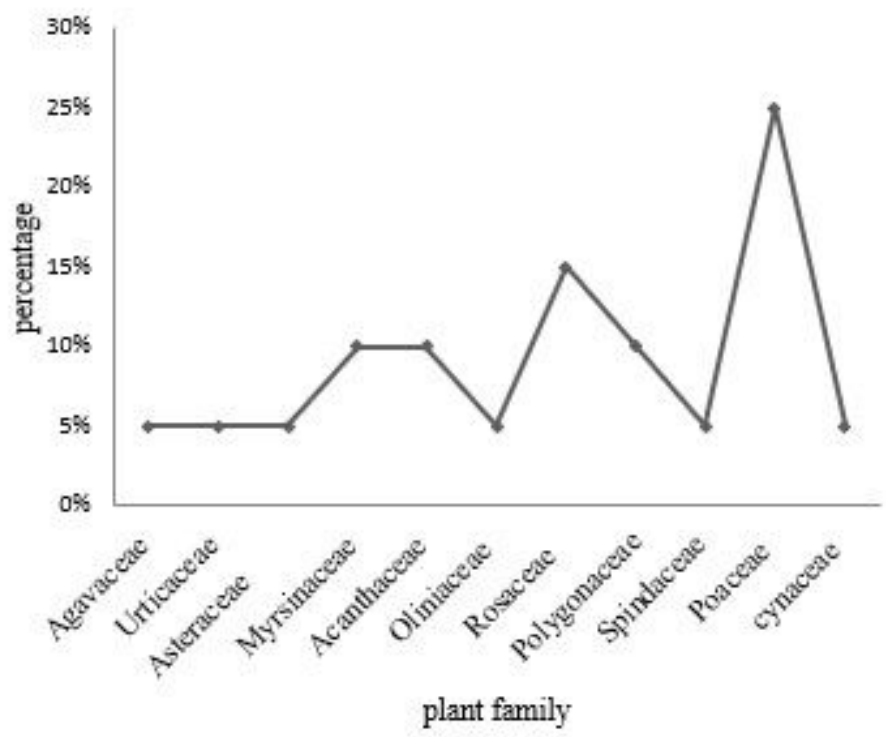




\section{Figure 3}

Of the identified list of plant species, $25 \%$ were Poaceae, $10 \%$ were Polygonaceae, $15 \%$ were Rosaceae ,10\% were Acanthaceae, $10 \%$ were Myrsinaceae and the other families shared 5\% (Fig. 3). The most commonly used plant species was Cynodon dyctylon (10.5\%), followed by Oplismenus composites (9.8\%) while Rumex nervosus vahl was least used (0.5\%).

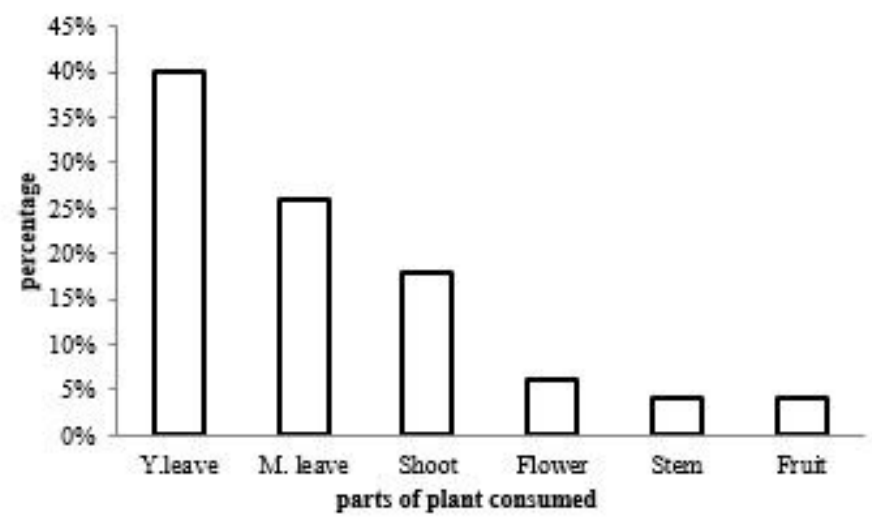

\section{Figure 4}

About $40 \%$ of the diet constituted young leaves followed by mature leaves (26\%). There was significant variation $\left(\chi^{\wedge} 2=98, d f=10, P<0.05\right)$ in parts of plant consumed by common bushbuck 